\title{
Gene discovery in an invasive tephritid model pest species, the Mediterranean fruit fly, Ceratitis capitata
}

\author{
Ludvik M Gomulski ${ }^{1}$, George Dimopoulos ${ }^{2}$, Zhiyong $\mathrm{Xi}^{2}$, Marcelo B Soares ${ }^{3}$, \\ Maria F Bonaldo ${ }^{3}$, Anna R Malacrida ${ }^{1}$ and Giuliano Gasperi*1
}

Address: ${ }^{1}$ Department of Animal Biology, University of Pavia, Piazza Botta 9, Pavia 27100, Italy, ${ }^{2}$ Johns Hopkins Bloomberg School of Public Health, Baltimore, MD 21205-2179, USA and 3Northwestern University's Feinberg School of Medicine, Chicago, IL 60614-3394, USA

Email: Ludvik M Gomulski - gomulski@unipv.it; George Dimopoulos - gdimopou@jhsph.edu; Zhiyong Xi - zxi@jhsph.edu; Marcelo B Soares - mbsoares@childrensmemorial.org; Maria F Bonaldo - mbonaldo@childrensmemorial.org; Anna R Malacrida - malacrid@unipv.it; Giuliano Gasperi* - gasperi@unipv.it

* Corresponding author

Published: 23 May 2008

BMC Genomics 2008, 9:243
Received: 6 February 2008

Accepted: 23 May 2008

This article is available from: http://www.biomedcentral.com//47/-2/64/9/243

(c) 2008 Gomulski et al; licensee BioMed Central Ltd.

This is an Open Access article distributed under the terms of the Creative Commons Attribution License (http://creativecommons.org/licenses/by/2.0), which permits unrestricted use, distribution, and reproduction in any medium, provided the original work is properly cited.

\begin{abstract}
Background: The medfly, Ceratitis capitata, is a highly invasive agricultural pest that has become a model insect for the development of biological control programs. Despite research into the behavior and classical and population genetics of this organism, the quantity of sequence data available is limited. We have utilized an expressed sequence tag (EST) approach to obtain detailed information on transcriptome signatures that relate to a variety of physiological systems in the medfly; this information emphasizes on reproduction, sex determination, and chemosensory perception, since the study was based on normalized cDNA libraries from embryos and adult heads.

Results: A total of 21,253 high-quality ESTs were obtained from the embryo and head libraries. Clustering analyses performed separately for each library resulted in 5201 embryo and 6684 head transcripts. Considering an estimated 19\% overlap in the transcriptomes of the two libraries, they represent about $96 / 4$ unique transcripts involved in a wide range of biological processes and molecular functions. Of particular interest are the sequences that share homology with Drosophila genes involved in sex determination, olfaction, and reproductive behavior. The medfly transformer2 (tra2) homolog was identified among the embryonic sequences, and its genomic organization and expression were characterized.

Conclusion: The sequences obtained in this study represent the first major dataset of expressed genes in a tephritid species of agricultural importance. This resource provides essential information to support the investigation of numerous questions regarding the biology of the medfly and other related species and also constitutes an invaluable tool for the annotation of complete genome sequences. Our study has revealed intriguing findings regarding the transcript regulation of tra2 and other sex determination genes, as well as insights into the comparative genomics of genes implicated in chemosensory reception and reproduction.
\end{abstract}




\section{Background}

The medfly, Ceratitis capitata, is a highly invasive agricultural pest species that has expanded from its native range in sub-Saharan Africa to become a cosmopolitan species in less than 200 years. Its success as an invasive species is partially due to its unusually wide host range and its ability to adapt to a wide range of climatic conditions and habitats [1]. As such, it has become the target of extensive control programs and a model organism for the sterile insect technique (SIT), a method considered to be among the most efficient and environmentally friendly control procedures $[2,3]$. This technique, designed to reduce the size of the target population, is based on the release of sterile males that compete for wild females. Indeed, the medfly was the first non-drosophilid organism to be transformed [4], with the goal of introducing genes capable of improving genetic sexing systems for the SIT. Although molecular genetics studies of the medfly began in the early 1990s, at present (January 2008) only 182 putative coding sequences are known, almost half of which are fragmentary [5]. This lack of molecular data is in sharp contrast to the mass of data that has been accrued on the classical and population genetics of this model insect.

The number of published complete genome sequences has grown exponentially since the first two bacterial genomes were reported in 1995, with over 600 available as of 2008 [6]. These genome sequences include a number of important insect genomes, such as those of Drosophila melanogaster, the malarial mosquito, Anopheles gambiae, the silkworm Bombyx mori, and the honeybee Apis mellifera [7-10]. Numerous other insect genome-sequencing projects are in progress, including those for numerous species of Drosophila, mosquitoes of the genera Aedes, Anopheles and Culex, the cotton bollworm Helicoverpa armigera, the tobacco budworm Heliothis virescens, the human louse Pediculus humanus, the vector of Chagas disease Rhodnius prolixus, the tsetse fly Glossina morsitans, the sandfly Lutzomyia longipalpis, parasitic wasps of the genus Nasonia, the flour beetle Tribolium castaneum, and several aphids and ticks $[6,11,12]$.

The initial goal of these genome sequence projects is to identify a complete set of genes and subsequently to determine their expression in different life stages and tissues and to characterize their regulation and function. Given that the haploid genome size of the medfly is relatively large $(540 \mathrm{Mb})$, three times larger than that of D. melanogaster, the sequencing of the complete genome would be prohibitively expensive except by a large consortium.

To address the lack of sequence data available for the medfly, we have initiated a functional genomics approach based on expressed sequence tags (ESTs). ESTs represent a relatively quick and inexpensive technology for discovering new genes, for obtaining data on their expression and regulation, and for the construction of genome maps [13]. They are an ideal means for the rapid exploration of transcriptomes, especially those of species with large genome sizes. ESTs can also form a very solid basis for evolutionary studies.

The genetic information obtained from this EST initiative will be of enormous value for identifying and determining the functions of genes involved in a number of important biological processes, including sex determination, sex differentiation, reproduction, courtship behavior, and olfaction. Such processes represent ideal targets for the development of novel control methods and pest-monitoring systems. To target these biological processes we have utilised cDNA libraries derived from medfly embryos and adult heads as the source of our ESTs. The embryo library permits the identification of genes involved in sex determination and development whereas the head library permits the identification of genes involved in different behaviours, in olfaction etc. The availability of a large number of transcripts also permits the development of oligonucleotide-based microarrays that will facilitate the study of these biological processes by means of mass expression profile analyses.

Apart from its economic importance, the medfly also represents an alternative model dipteran species. Drosophila melanogaster is the model dipteran par excellence, but in many ways it is an atypical species. The availability of mosquito genomes has helped to balance this bias, and hopefully the medfly data presented here will also contribute to that end.

Here we present a comprehensive EST-based gene discovery project that has provided sequences of 11,885 transcripts and yielded novel insights into various biological activities of an important agricultural pest, the medfly.

\section{Results and Discussion}

Generation and assembly of medfly embryo and head ESTs Two unidirectional, normalized cDNA libraries were constructed from embryos ranging in age from $30 \mathrm{~min}$ to 36 hr after oviposition and from adult male and female heads of flies ranging from $30 \mathrm{~min}$ to 8 days after emergence. Thus, the embryo library is representative of the transcriptome of embryos at different stages of development. The head library is representative of the transcriptome of adult heads of both sexes and different physiological states (immature, virgin, mated).

A total of 24,030 random cDNA clones from the two libraries were sequenced from the $5^{\prime}$ end. These sequences, once trimmed of vector, contaminants, and 
low-quality sequences, yielded a total of 21,253 highquality masked ESTs, with an average length of $700 \mathrm{bp}$ for the embryo sequences and $723 \mathrm{bp}$ for the head sequences, and representing over 15 megabases of medfly sequence.

The sequences from the two libraries were assembled separately using the Phrap program [14]: 7,173 of the embryo ESTs were assembled into 2,107 contiguous sequences (contigs), and the remaining 3,094 ESTs that were not redundant were classified as singlets. For the head ESTs, assembly resulted in 2,785 contigs (from 7087 ESTs) and 3,899 singlets. Contigs and singlets derived from the embryo ESTs are given the prefixes FC and FS, respectively, followed by a number. The head contigs and singlets have the prefixes HC and HS, respectively. The phrap program produces contigs consisting of a single-read which represent sequences that produced a match with other sequences but that could not be consistently assembled with these other reads. The highest number of ESTs in a single contig was 206 (HC2785), but very few contigs contained more than 10 ESTs. The distribution of the ESTs in contigs and singlets is illustrated in Table 1.

Almost 55\% of the assembled embryo sequences and 29\% of the assembled head sequences contained open reading frames (ORFs) with start codons that potentially encode at least 150 amino acids. However, given that ESTs are single-read sequences and that 5 -truncated cDNA inserts are not uncommon, we obtained a less stringent estimate of $69 \%$ for the embryo sequences and 36\% for the head sequences when the presence or absence of the start codon was ignored (Table 1).

The sequences that lacked a putative ORF produced $43 \%$ hits in the case of the embryo library and only $19 \%$ hits for the head library. Of the assembled sequences containing a putative ORF, $89 \%$ of those derived from both the head and the embryo libraries had BLASTX matches in the non-redundant (nr) database. Subsequent TBLASTX analyses against the insecta set of EST sequences in the dbEST database increased this percentage to $91 \%$ in the embryo and $92 \%$ in the head. This finding suggests that perhaps $9 \%$ of the medfly transcripts, from the embryo or head, are highly divergent from their homologs in other organisms. It is probable that many of the sequences without putative ORFs and BLAST matches are non-coding sequences and may represent 5' or 3' UTRs.

Consistent with the expectation that the cDNA clones were sequenced from the 5 ' end, $98.4 \%$ of the assembled embryo sequences and $93.8 \%$ of the head sequences with hits in the nr database were encoded on the forward strand. The small proportion of assembled sequences that appeared to be encoded on the reverse strand may be the result of the cDNA being inserted in the opposite direction in the vector.

Almost $75 \%$ of the assembled embryo sequences and $44 \%$ of the assembled head sequences produced BLASTX hits against the nr database with an expectation, $e$, of less than $10^{-5}$. Well over $90 \%$ of the best hits were arthropodderived sequences. Not surprisingly, of these arthropod sequences, $90 \%$ were Drosophila sequences, and of these, more than half pertained to D. melanogaster (Additional file 1, Table S1).

Only 58 of the best hits ( 18 for embryo and 40 for head sequences) were against $C$. capitata sequences, a finding that reflects the scarcity of medfly sequences in the databases (Additional file 2, Table S2). BLASTN analysis showed that three of the 13 sequences identified from a medfly male accessory gland cDNA library [GenBank:DQ406807, DQ406810, DQ406812] [15] were represented in the embryo (FC2089) and head assembled sequences (HC1979, HC2078, HC2666, HC2668). This finding has no bearing on the specificities of our libraries

Table I: EST assembly statistics

\begin{tabular}{lcc}
\hline & Embryo Library & Head Library \\
\hline Number of sequences & 11512 & 12518 \\
Number of high quality sequences & 10267 & 10986 \\
Number of putative transcripts (assembled sequences) & 5201 & 6684 \\
Number of contigs & 2107 & 3094 \\
Number of singlets & 3785 \\
Number of contigs containing: & 130 & 3899 \\
I EST & 1649 & 825 \\
$2-4$ ESTs & 274 & 1734 \\
5-IO ESTs & 38 & 193 \\
II-20 ESTs & 11 & 23 \\
$>40$ ESTs & 38 & 8 \\
Mean assembled sequence length (bp) & 5 & 2 \\
\end{tabular}


as all three genes (Antigen-r5, Jafrac1 and virus-induced $R N A 1$ ) are putatively involved in the immune pathway and in Drosophila are expressed in embryos and/or other adult tissues including the head.

Fifteen of the embryonic assembled sequences and 44 of the head sequences appeared to be of viral origin. Thirteen assembled sequences showed significant amino acid similarity to the polyproteins of the sacbrood [GenBank:AAT45735] and 16 to the Kakugo viruses [GenBank:NC 005876] previously identified in the honeybee. Another three sequences showed significant amino acid similarity to a virus polyprotein sequence isolated from Varroa destructor mites living on honeybee larvae. Twenty-three sequences showed significant amino acid identity to a cysteine-rich repetitive sequence in the U88 gene of the human herpesvirus 6 [GenBank:NC 001664] and another similarity to a highly repetitive sequence within the latency associated antigen gene of the ovine herpesvirus 2 [GenBank:AAL05844]. Single sequences showed similarity with the RNA-dependent RNA polymerase region of the $183-\mathrm{kDa}$ protein of the Odontoglossum ringspot virus, the polymerase subunit of the influenza $\mathrm{C}$ virus, and the putative viral replicase of the prune dwarf virus. It is possible that some of these sequences represent retroviral elements.

Only 20 sequences appeared to have originated from the fly's bacterial flora, with homology to bacterial sequences of the genera Bacteroides, Burkholderia, Escherichia, Haemophilus, Magnetococcus, or Staphylococcus.

Sixty three of the transcripts showed significant homology to transposable elements; 11 of these were from the embryo library and the remaining 52 from the head library. The majority of these putative transposable elements belonged to the mariner (44) and Tc1 (15) families of transposable elements, but elements related to $h A T$ family (two sequences, one to an element from Danio rerio and another to hermit from Lucilia cuprina), and to retrotransposons (two sequences related to the D. melanogaster 1731 retrotransposon) were also detected. The best hits for almost two-thirds of the mariner-like elements identified were previously identified elements from C. capitata or Ceratitis rosa (e values ranged from $1 e-6$ to $5 e-25$ ) [16].

\section{Annotation of the assembled sequences}

The medfly ESTs were annotated with respect to D. melanogaster, which is not only the most extensively annotated genome but also relatively close to the medfly in evolutionary terms. Both species are members of the Acalyptratae and are estimated to have diverged from a common ancestor $80-100$ million years ago $[17,18]$. Each medfly assembled sequence and singlet was assigned a gene ontology (GO) classification based the annotation of the best-hit D. melanogaster peptide obtained in BLASTX searches; thus, our annotations are at the "inferred from electronic annotation" (IEA) level of evidence. To avoid potential compounding of errors, Drosophila annotations assigned at the IEA level were not considered for the annotation of the medfly ESTs.

Of the 5,201 assembled embryo sequences, $74.5 \%$ (3876) produced best hits with an expectation, $e$, of $<10^{-5}$ against the Drosophila peptide database (containing 19,178 peptides), and 51.9\% (2699) were assigned GO annotations. In the case of the head sequences, $39.6 \%(2,649$ of 6,684$)$ produced hits, and $31.1 \%(2,077)$ were assigned GO annotations.

The 5,201 embryo-derived and 6,684 head-derived assembled sequences presumably represent distinct transcripts. However, these numbers are likely to be an overestimate of the actual number of transcripts obtained, because ESTs derived from the same gene may not have been assembled into a single contig because of alternative splicing or sequence polymorphism. A total of 3,876 assembled embryo sequences produced best hits with 3,290 different $D$. melanogaster genes, suggesting a $15.1 \%$ redundancy in the assembled sequences. Extrapolating this redundancy value to the complete dataset, we estimate that the 5,201 assembled sequences represent about 4,400 genes expressed in the embryo. Likewise, for the head sequences, a total of 2,649 assembled medfly head sequences produced best hits with 2,304 different $D$. melanogaster genes, a $13 \%$ redundancy in the assembled sequences; thus, the 6,684 assembled sequences may represent about 5,815 genes expressed in the adult head.

Clearly, we can expect that there will be some overlap in the genes expressed in the sequences derived from the embryo and head library. To determine the extent of this overlap, the ESTs from the two libraries were pooled and reassembled using Phrap. This procedure generated a total of 9,614 assembled sequences $(4,185$ contigs and 5,429 singlets). Given that the two libraries when assembled separately gave rise to a total of 11,885 assembled sequences, we can estimate that approximately 2,271 sequences were shared between the two libraries, for an overlap of about $19 \%$.

A summary of the allocation of the annotations to specific biological processes and molecular functions as classified by GO is presented in Additional files 3 and 4, Tables S3 and $\mathrm{S} 4$. A wide range of processes and functions are represented. Of particular interest in terms of the development of novel control methods for this pest species are the annotations related to sex determination, olfaction, and reproductive behavior. 


\section{Genes involved in sex determination}

In Drosophila, the primary sex determinant is the ratio of the number of $\mathrm{X}$ chromosomes to the number of sets of autosomes. When the ratio is 1 (XX:AA), the master switch gene, Sex lethal $(S x l)$, is activated and sets in motion a cascade of regulatory genes, transformer (tra), transformer-2 (tra2) and doublesex $(d s x)$, that result in female development. When the ratio is 0.5 (X:AA), $S x l$ is not activated, and male development proceeds. Although the medfly sex determination cascade is only partially characterized, it is clear that the initial levels differ from those of Drosophila. In the medfly, the primary sex determinant is a maledetermining factor $(\mathrm{M})$ on the $\mathrm{Y}$ chromosome. Thus, XX embryos develop into females and $\mathrm{XY}$ embryos into males. The medfly homolog of tra, Cctra, acts as the switch gene rather than the homologue of $S x l, C c S x l$. The active product of the Cctra gene, CCTRA, which is present only in females, directs female-specific splicing of the doublesex $(d s x)$ pre-mRNAs [19-21]. In this respect, the medfly sex determination pathway appears to have a greater affinity to that of Musca domestica than to that of Drosophila [22].

Of the three sex determination genes previously described in the medfly, $C c S x l, C c d s x$, and Cctra, only $C c S x l$ was identified among the medfly assembled sequences (Additional file 2, Table S2). However, 24 of the medfly assembled sequences shared homology with 13 Drosophila genes that have been implicated in sex determination (Table 2). Of particular interest was the sequence FC1744 from the embryo library, which shared 57\%/73\% amino acid identity/homology with the transformer 2 (tra2) sequence of $D$. melanogaster. FC1744 appears to be a full-length tra2 transcript. In Drosophila tra2 encodes a splicing regulator protein that contains an RNA recognition motif (RRM) flanked by two regions rich in arginine and serine residues (RS domains). The existence of a medfly tra2 homologue, Cctra2, has been hypothesized [20,21] but has not previously been described. It is thought that the CcTRA2 protein might interact with CcTRA to control both femalespecific splicing of $C c d s x$ and the positive feedback loop established by the Cctra gene. The Ccdsx sequence contains conserved TRA/TRA2 binding sites close to the regulated splice site, suggesting that both TRA and TRA2 proteins are involved in the splicing process [20,21].

The genomic sequence of the Cctra 2 gene, amplified using a pair of primers designed in the 5' and 3' UTRs on the cDNA sequence of FC1744, is over $2.6 \mathrm{~kb}$ in length. Comparison of the genomic and CDNA sequences revealed the presence of eight exons ( $34-176 \mathrm{bp}$ in length) and seven introns (64 - $834 \mathrm{bp}$ in length). The splice sites all conformed to the GT-AG rule [23]. The positions of the introns were conserved with respect to the other tephritid tra-2 sequence from Bactrocera oleae [GenBank:AJ547623] and that of $M$. domestica [GenBank:AY847518]. The tra2 gene of $D$. melanogaster has seven exons rather than the eight present in Cctra2. This difference appears to be the result of the presence of an extra intron in Cctra2 within

Table 2: Medfly assembled sequences with best-hit matches to $D$. melanogaster genes involved in sex determination

\begin{tabular}{|c|c|c|c|c|c|}
\hline Medfly Sequence & Drosophila gene & Alignment Length (aa) & e-Value & Identity (\%) & Similarity (\%) \\
\hline FC662 & groucho (gro) & 82 & $6 \mathrm{E}-07$ & 29 & 50 \\
\hline FCl046 & sisterless $A(\operatorname{sis} A)$ & 180 & $3 E-13$ & 26 & 49 \\
\hline $\mathrm{FCl} 310$ & female lethal $d(f(2) d)$ & 493 & $3 \mathrm{E}-91$ & 47 & 53 \\
\hline $\mathrm{FCl} 664$ & sans fille (snf) & 216 & $2 \mathrm{E}-99$ & 84 & 88 \\
\hline FCI 744 & transformer 2 (tra2) & 106 & $9 \mathrm{E}-32$ & 57 & 73 \\
\hline FC200I & intersex (ix) & 142 & $2 \mathrm{E}-54$ & 71 & 85 \\
\hline FSII09 & hopscotch (hop) & 248 & $4 \mathrm{E}-50$ & 39 & 63 \\
\hline FSI4I9 & deadpan (dpn) & 48 & IE- 10 & 75 & 83 \\
\hline $\mathrm{FSI} 1610$ & Mes-4 & 160 & IE-62 & 65 & 80 \\
\hline FSI866 & groucho (gro) & 217 & IE- 126 & 97 & 98 \\
\hline FS2679 & Mes-4 & 161 & $2 \mathrm{E}-42$ & 40 & 54 \\
\hline FS2848 & Mes-4 & 147 & $2 \mathrm{E}-19$ & 36 & 51 \\
\hline $\mathrm{HCI} 587$ & modifier of mdg4 $(\bmod (m d g 4))$ & 97 & $4 \mathrm{E}-34$ & 60 & 80 \\
\hline $\mathrm{HC} 2665$ & lola like (Iolal) & 127 & $9 \mathrm{E}-68$ & 99 & 99 \\
\hline HS375 & sans fille (snf) & 80 & IE-39 & 97 & 98 \\
\hline HS438 & modifier of mdg4 $(\bmod (\operatorname{mdg} 4))$ & 61 & $2 \mathrm{E}-16$ & 55 & 70 \\
\hline HS653 & longitudinals lacking (lola) & 39 & $3 \mathrm{E}-18$ & 100 & 100 \\
\hline HS900 & modifier of mdg4 $(\bmod (m d g 4))$ & 263 & $7 \mathrm{E}-74$ & 58 & 69 \\
\hline HSII76 & modifier of mdg4 $(\bmod (m d g 4))$ & 73 & $3 \mathrm{E}-28$ & 73 & 89 \\
\hline HSI648 & CG3726 & 94 & $|E-3|$ & 71 & 79 \\
\hline HS239I & modifier of mdg4 $(\bmod (m d g 4))$ & 114 & IE-37 & 57 & 78 \\
\hline HS2544 & longitudinals lacking (lola) & 247 & $\mathrm{IE}-62$ & 52 & 61 \\
\hline HS2947 & longitudinals lacking (lola) & 104 & IE-50 & 83 & 89 \\
\hline HS3522 & modifier of mdg4 $(\bmod (\operatorname{mdg} 4))$ & 94 & $\mathrm{IE}-\mathrm{I} 7$ & 46 & 67 \\
\hline
\end{tabular}


the Drosophila equivalent of exon 6. Furthermore, only two of the intron positions were conserved with respect to the Drosophila tra2. Figure 1 illustrates the cDNA sequence and the deduced 251 amino acid sequence of Cctra2. Amino acids 106 to 177 represent an RNA recognition motif (RRM) (e value, 7e-10) diagnostic of an RNA-binding protein [24]. The RRM is flanked by two arginine-rich/ serine-rich regions (RS domains), which mediate proteinprotein interactions to facilitate the formation of spliceosomal and regulatory splicing complexes [25]. Examination of the four EST sequences that comprise FC1744 revealed no indication of alternative splicing of the Cctra2 gene. RT-PCR analysis of different development stages/tissues (embryos, male and female larvae, adult heads and adult bodies) with primers located in the 5' UTR and exon 7 produced a single product of about 840 bp in each case, suggesting that the gene is not alternatively spliced (data not shown). The gene was expressed in both sexes and in all the life stages examined, although the transcripts present in the very early embryos may be of maternal origin. This expression pattern is very similar to that of $M$. domestica [22] but very different from that of D. melanogaster where at least five different tra2 transcripts are known, resulting from alternative promotors and differential splicing [26]. In Drosophila, the somatic transcripts are not sex-specific but two alternatively spliced transcripts are found only in the male germline [26].

The highest identity/similarity of the Cctra2 amino acid sequence was with the tra2 homologue from $B$. oleae (Botra2) ([GenBank:CAD67988]; 88\%/93\%). The phylogenetic relationships of the tra2 amino acid sequences from C. capitata, B. oleae, M. domestica [GenBank:AAW34233], D. melanogaster [GenBank:AAA62771], D. virilis [GenBank:AAB58114], D. pseudoobscura [GenBank:XP 001360605], A. mellifera [GenBank:XP 001121070], Nasonia vitripennis [GenBank:XP 001601106], and Bombyx mori [GenBank:AAX47001] are represented in the neighbor-joining tree (Figure 2). The sequences cluster according to the taxonomic relationships of the insect species. Thus, Cctra2 clusters with the other tephritid sequence Botra2 from $B$. oleae, and the two hymenopteran sequences, Amtra2 and Nvtra2, form a well-supported cluster, as do the three Drosophila sequences. In both trees, the tra2 products of the Tephritidae (Acalyptrate) appear to be more closely related to that of $M$. domestica (Calyptrate) than to those of the Drosophilidae (Acalyptrate). This topology is in agreement with those inferred from glucose-6-phosphate dehydrogenase [27], white [28], and alcohol dehydrogenase [29] and supports the evolutionary hypothesis in which the Tephritidae are closer to the Calyptrate Calliphoridae than to the Acalyptrate Drosophilidae [30]. The greater affinity of the medfly sex-determination system to that of the housefly than to that of Drosophila is further evidence of this evolutionary relationship [22].

Apart from their role in sex-determination, tra2 genes are also involved in male courtship behavior. The TRA2 protein interacts with TRA to regulate splicing of the fruitless gene (fru). Male-specific fru transcripts are essential for male courtship behavior [31,32].

Three of the other medfly assembled sequences that are putatively involved in sex determination share sequence homology with members of the three classes of primary $\mathrm{X}$ :A signal genes that encode transcription factors that regulate $S x l$ expression in Drosophila. The sisterless A gene belongs to the numerator class of primary signal genes and positively regulates $S x l$, whereas deadpan is the only known denominator gene and negatively regulates $S x l$. The third class of primary signal genes is represented by groucho, a maternal gene whose product is also a negative regulator of Sxl. The genes female lethal(2)d and sans fille are also involved in the autoregulation of Sxl. Intersex is required for the activity of DSXF, the female transcription factor product of doublesex [33]. In addition to their potential usefulness in comparative studies of the sex determination pathways, these genes and others expressed during embryogenesis may be useful for the development of genetic sexing strains and as targets for pest control programs.

\section{Genes involved in olfaction}

The biological success, and hence the economic impact, of the medfly can be ascribed in part to the sensitivity and selectivity of its olfactory systems, which are essential for the location of plant hosts and for the detection of pheromones during the recognition and location of mates [34].

The olfactory signal transduction cascade in insects is facilitated by three main groups of molecules: odorantbinding proteins (OBPs), odorant receptors (ORs), and odorant-degrading enzymes (ODEs) [35]. A group of OBPs, the pheromone binding proteins (PBPs), are expressed in pheromone-responsive sensilla and bind to pheromone molecules [36].

OBPs are small, water-soluble proteins that are present in high concentration in olfactory and gustatory sensilla [37]. They are thought to solubilize hydrophobic odorant molecules and transport them through the hydrophilic environment in the hemolymph to the ORs on the cell surface. However, given the large number of OBPs present in many insect species, many of which display different odorant-binding specificities, it is probable that they play an active role in odorant recognition, perhaps acting as selective filters rather than as passive odorant shuttles 


\section{A}

1 CACACAGCAA GCGgGCATTT TTATTTCAAT CAgCGgTAGC TTGTGAAAAA TTGAGAAAAA

61 TTATTGCTGT TAGTTTACAA CGTTTAATAA GTAGAAAATT AATATATAAA TAACATAGAA

121 AAGCTGGAAT GAGTCCACGT TCACGTAGCC GAAGCATTTC CGCACGTCGC AGTTATACCA

$\begin{array}{lllllllllllllllll}M & S & P & R & S & R & S & R & S & I & S & A & R & R & S & Y & T\end{array}$

181 AGTCGCCTGC TCGACGCAGC AATGGACGCC GCCGGCATTC CAGAGAAAAG GTTTATAAAT \begin{tabular}{lllllllllllllllllllll}
$K$ & $\mathrm{~S}$ & $\mathrm{P}$ & $\mathrm{A}$ & $\mathrm{R}$ & $\mathrm{R}$ & $\mathrm{S}$ & $\mathrm{N}$ & $\mathrm{G}$ & $\mathrm{R}$ & $\mathrm{R}$ & $\mathrm{R}$ & $\mathrm{H}$ & $\mathrm{S}$ & $\mathrm{R}$ & $\mathrm{E}$ & $\mathrm{K}$ & $\mathrm{V}$ & $\mathrm{Y}$ & $\mathrm{K}$ \\
\hline
\end{tabular}

241 CTCGCAGCCG TTCAATTTCA CGACACCCGC CTTCACCACC GCCACCGCCT ACAGGACGTG \begin{tabular}{llllllllllllllllllll}
$\mathrm{S}$ & $\mathrm{R}$ & $\mathrm{S}$ & $\mathrm{R}$ & $\mathrm{S}$ & $\mathrm{I}$ & $\mathrm{S}$ & $\mathrm{R}$ & $\mathrm{H}$ & $\mathrm{P}$ & $\mathrm{P}$ & $\mathrm{S}$ & $\mathrm{P}$ & $\mathrm{P}$ & $\mathrm{P}$ & $\mathrm{P}$ & $\mathrm{P}$ & $\mathrm{T}$ & $\mathrm{G}$ & $\mathrm{R}$ \\
\hline
\end{tabular}

301 GTGGTGTTCG CTGTTCAGAT GCCAGCCAAA GTTCTTCAAC GTCACTATCA CCACGGCAAG

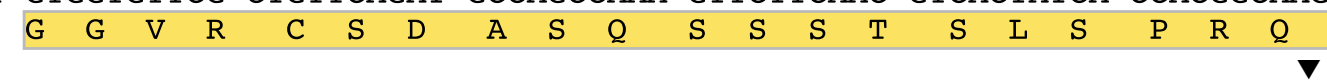

361 GCCGTCGGAT GTCACGTTCC CGTTCTCGCA GTCCATACGA TAAGCGACGC GGCAATAGAG $\begin{array}{lllllllllllllllllllll}\mathrm{G} & \mathrm{R} & \mathrm{R} & \mathrm{M} & \mathrm{S} & \mathrm{R} & \mathrm{S} & \mathrm{R} & \mathrm{S} & \mathrm{R} & \mathrm{S} & \mathrm{P} & \mathrm{Y} & \mathrm{D} & \mathrm{K} & \mathrm{R} & \mathrm{R} & \mathrm{G} & \mathrm{N} & \mathrm{R}\end{array}$

421 AAAAACCAGT ACAAAACCGT TGTATAGGAG TTTTTGGTTT GAGTGTTTAT ACAACGCAAC $\begin{array}{llllllllllllllllllllll}\mathrm{E} & \mathrm{K} & \mathrm{P} & \mathrm{V} & \mathrm{Q} & \mathrm{N} & \mathrm{R} & \mathrm{C} & \mathrm{I} & \mathrm{G} & \mathrm{V} & \mathrm{F} & \mathrm{G} & \mathrm{L} & \mathrm{S} & \mathrm{V} & \mathrm{Y} & \mathrm{T} & \mathrm{T} & \mathrm{Q} & 1\end{array}$

481 AAAAAATACG TGATATATTC TCTAGATTTG GACCAATCGA GAGGATACAA GTAGTCATTG $\begin{array}{lllllllllllllllllllllll}\mathrm{Q} & \mathrm{K} & \mathrm{I} & \mathrm{R} & \mathrm{D} & \mathrm{I} & \mathrm{F} & \mathrm{S} & \mathrm{R} & \mathrm{F} & \mathrm{G} & \mathrm{P} & \mathrm{I} & \mathrm{E} & \mathrm{R} & \mathrm{I} & \mathrm{Q} & \mathrm{V} & \mathrm{V} & \mathrm{I}\end{array}$

541 ATGCACAGAC TGGCCGATCT CGTGGCTTTT GCTTTATCTA TTATGATGAT ATAGCTGATG $\begin{array}{llllllllllllllllllllll}\mathrm{D} & \mathrm{A} & \mathrm{Q} & \mathrm{T} & \mathrm{G} & \mathrm{R} & \mathrm{S} & \mathrm{R} & \mathrm{G} & \mathrm{F} & \mathrm{C} & \mathrm{F} & \mathrm{I} & \mathrm{Y} & \mathrm{Y} & \mathrm{D} & \mathrm{D} & \mathrm{I} & \mathrm{A} & \mathrm{D} & 157\end{array}$

601 CTAAGGCAGC CAAGgACGCA TGTTCCGgCA TGGAAATCGA TGATCGACGC ATACGCGTAG $\begin{array}{lllllllllllllllllllll}\text { A } & \text { K } & \text { A } & \text { A } & \text { K } & \text { D } & \text { A } & \text { C } & \text { S } & \text { G } & \text { M } & \text { E } & \text { I } & \text { D } & \text { D } & \text { R } & \text { R } & \text { I } & \text { R } & \text { V } & 177\end{array}$

661 ATTACTCAAC TACACAGAGA CCACACACTC CCACACCTGG CGTTTATATG GgACGACACA $\begin{array}{llllllllllllllllllllll}\mathrm{D} & \mathrm{Y} & \mathrm{S} & \mathrm{T} & \mathrm{T} & \mathrm{Q} & \mathrm{R} & \mathrm{P} & \mathrm{H} & \mathrm{T} & \mathrm{P} & \mathrm{T} & \mathrm{P} & \mathrm{G} & \mathrm{V} & \mathrm{Y} & \mathrm{M} & \mathrm{G} & \mathrm{R} & \mathrm{H} & 197\end{array}$

721 CAAGGCGTGA ACGTGAATAT AATGATCGTT ATCGCGATGA CTACCGTCCC CGCCGTCGTT \begin{tabular}{l|lllllllllllllllllllll}
$\mathrm{T}$ & $\mathrm{R}$ & $\mathrm{R}$ & $\mathrm{E}$ & $\mathrm{R}$ & $\mathrm{E}$ & $\mathrm{Y}$ & $\mathrm{N}$ & $\mathrm{D}$ & $\mathrm{R}$ & $\mathrm{Y}$ & $\mathrm{R}$ & $\mathrm{D}$ & $\mathrm{D}$ & $\mathrm{Y}$ & $\mathrm{R}$ & $\mathrm{P}$ & $\mathrm{R}$ & $\mathrm{R}$ & $\mathrm{R}$ & 217
\end{tabular}

781 CAGGTTCACC CTTTAAGAAT CGTAACAATT ATCGTAACGA TCGTAGgCGT CGATATGATC $\begin{array}{|lllllllllllllllllllllll|}\mathrm{S} & \mathrm{G} & \mathrm{S} & \mathrm{P} & \mathrm{F} & \mathrm{K} & \mathrm{N} & \mathrm{R} & \mathrm{N} & \mathrm{N} & \mathrm{Y} & \mathrm{R} & \mathrm{N} & \mathrm{D} & \mathrm{R} & \mathrm{R} & \mathrm{R} & \mathrm{R} & \mathrm{Y} & \mathrm{D} & 237\end{array}$

841 GAAGCCGTAG TCGTTCCTAT TCGCCACGGC GTGCACGTTA TTAGAACTGT TCCATGTAAA \begin{tabular}{lllllllllllll|lllll}
$R$ & $S$ & $R$ & $S$ & $R$ & $S$ & $Y$ & $S$ & $P$ & $R$ & $R$ & $A$ & $R$ & $Y$ & $*$ & 251
\end{tabular}

901 AAAAAAAAAA AAAAA

B

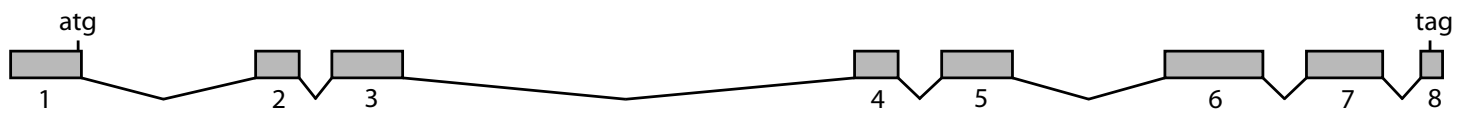

$500 \mathrm{bp}$

\section{Figure I}

(A) Nucleotide and deduced amino acid sequences of the Ceratitis capitata tra2 gene (Cctra2) cDNA. The RNA recognition motif (RRM) is boxed in blue. The two arginine-rich/serine-rich regions (RS-domains) are boxed in yellow. The positions of the introns are indicated by triangles. (B) Genomic organization of the Cctra2 gene. The genomic sequence has been deposited in GenBank (accession no. EU437408). 


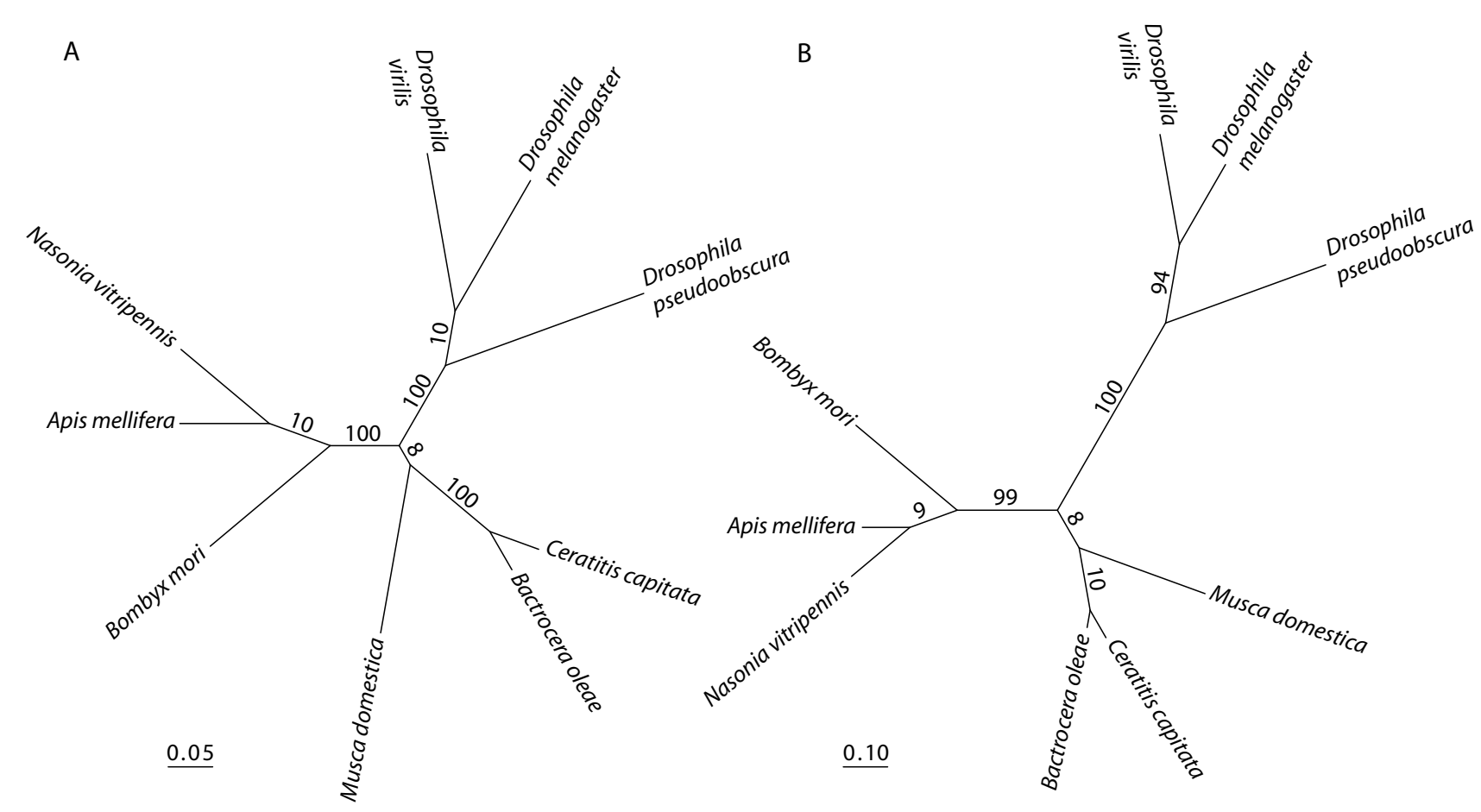

Figure 2

Phylogenetic analyses of the tra2 amino acid sequences from C. capitata, B. oleae (Botra2), M. domestica, D. melanogaster, D. virilis, D. pseudoobscura, A. mellifera, N. vitripennis, and B. mori. A. Neighbor-joining minimum evolution tree (ME-score $=1.750)$ with bootstrap values (percentage of 10,000 replications). The scale represents the mean character distance. B. Maximum-likelihood tree based on the Jones-Taylor-Thornton model of amino acid change (Ln Likelihood $=-4070.80)$ with bootstrap values (percentage of 100 replications). The scale represents the expected number of amino acid substitutions per position.

$[38,39]$. Once the odorant/OBP complex has bound to the receptor, the OBP may be actively involved in terminating signal transmission by inactivating the odorant molecule [40].

Fifty-one potential OBP genes have been identified in $D$. melanogaster [38]. BLASTX analyses identified 29 medfly sequences with significant hits to 12 different Drosophila OBP genes (Table 3 ). All but two of these putative medfly OBP genes were derived from the head library. Fourteen of these putative OBPs that produced hits with the Obp99c gene also gave very significant hits with the previously identified medfly male-specific serum polypeptide (MSSP) family of genes $[41,42]$. These MSSP sequences are presumably members of the minus-C subfamily of OBPs, since they do not contain all six of the conserved cysteine residues that characterize insect OBPs [40]. The MMSPs, of which there are at least seven members classified into three subgroups, $\alpha, \beta$ and $\gamma$, appear to be nonolfactory OBPs, and it has been hypothesized that they may be involved in the binding and transportation of male specific sex pheromones [42].
Another putative OBP was identified during the BLASTX analyses against the nr database. The sequence HS1065, again a head-derived sequence, shares $71 / 88 \%$ amino acid identity/similarity (alignment length $=120 \mathrm{aa}, e=2 \mathrm{E}$ 50) with the An. gambiae gene Obp1 [43].

ORs are a group of transmembrane proteins with very diverse sequences. The OBP/odorant complex interacts with the OR to initiate signal transmission from the outside of the neuron to the inside. Two putative medfly OR genes were identified in the head library (Table 4), one with a complete coding sequence with high amino acid identity to Drosophila Or83b. Or83b, unlike other OR genes, is highly conserved in other insects, and its presence is essential for olfaction. In fact, the Or83b homolog has already been isolated in the medfly [44] (Additional file 2, Table S2). The other putative medfly OR (HS336) identified in the head library shares homology with the Drosophila Or59a gene, which is expressed in the dorsal organ dome on the larval head, where it is involved in the detection of food odors, and particularly aromatic compounds containing a benzene ring [45-47]. Or59a appears not to be expressed in adult Drosophila olfactory organs 
Table 3: Medfly assembled sequences with best-hit matches to $D$. melanogaster odorant binding protein genes

\begin{tabular}{|c|c|c|c|c|c|}
\hline & Drosophila Gene & Alignment Length (aa) & e-Value & Identity (\%) & Similarity (\%) \\
\hline FS806 & Obp8a & 114 & $8 \mathrm{E}-15$ & 33 & 52 \\
\hline FSI734 & Obp84a/Pbprp4 & 73 & IE-I5 & 46 & 63 \\
\hline $\mathrm{HCl} 44$ & Obp99c & 108 & $3 \mathrm{E}-14$ & 38 & 51 \\
\hline $\mathrm{HC} 245$ & Obp99c & 108 & $4 \mathrm{E}-15$ & 39 & 53 \\
\hline HC522 & Obp99c & 106 & $7 E-17$ & 38 & 53 \\
\hline $\mathrm{HC} 725$ & Obp56d & 114 & $5 \mathrm{E}-24$ & 41 & 64 \\
\hline $\mathrm{HC745}$ & Obp99c & 106 & $3 \mathrm{E}-14$ & 40 & 53 \\
\hline HC984 & Obp99c & 112 & $8 \mathrm{E}-18$ & 38 & 54 \\
\hline $\mathrm{HClOI} 2$ & Obp56d & 114 & $5 \mathrm{E}-24$ & 41 & 64 \\
\hline $\mathrm{HCl} 070$ & Obp99c & 100 & $8 \mathrm{E}-11$ & 36 & 50 \\
\hline HCI099 & Obp99c & 104 & $8 \mathrm{E}-13$ & 37 & 51 \\
\hline $\mathrm{HCl} / 47$ & Obp99c & 104 & $8 \mathrm{E}-13$ & 37 & 51 \\
\hline $\mathrm{HCl} 32 \mathrm{I}$ & Obp56h & 126 & IE-I5 & 34 & 55 \\
\hline $\mathrm{HCl} 480$ & Obp99c & 108 & $7 E-16$ & 40 & 54 \\
\hline $\mathrm{HCI} 570$ & Obp28a/Pbprp5 & 122 & $2 \mathrm{E}-27$ & 45 & 59 \\
\hline $\mathrm{HCl} 629$ & Obp69a/Pbprpl & 126 & $4 \mathrm{E}-23$ & 38 & 62 \\
\hline $\mathrm{HCl} 947$ & Obp $19 a$ & 124 & IE-39 & 60 & 78 \\
\hline HC2050 & Obp99c & 105 & $\mid E-12$ & 38 & 53 \\
\hline HC2054 & Obp44a & 124 & $|E-4|$ & 62 & 77 \\
\hline HC2068 & Obp99c & 114 & $8 E-19$ & 39 & 55 \\
\hline HC2265 & Obp 19d/Pbprp2 & 110 & $7 E-23$ & 42 & 64 \\
\hline $\mathrm{HC} 2316$ & Obp99c & 112 & IE- 17 & 38 & 54 \\
\hline $\mathrm{HC} 2492$ & Obp99c & 117 & $2 \mathrm{E}-15$ & 39 & 51 \\
\hline HC2536 & Obp83a/Pbprp3 & 157 & $4 \mathrm{E}-62$ & 68 & 78 \\
\hline HSI079 & $O b p / 9 b$ & 149 & $5 E-26$ & 37 & 57 \\
\hline HS2I 27 & Obp99c & 107 & $2 \mathrm{E}-17$ & 39 & 59 \\
\hline HS2225 & Obp84a/Pbprp4 & 64 & $2 \mathrm{E}-15$ & 53 & 71 \\
\hline HS2969 & Obp84a/Pbprp4 & 112 & $9 \mathrm{E}-24$ & 44 & 61 \\
\hline HS3757 & Obp 19d/Pbprp2 & 110 & $4 \mathrm{E}-12$ & 32 & 55 \\
\hline
\end{tabular}

[48] but is maximally expressed in the male accessory glands of adult Drosophila [49]. At least 60 putative OR genes have been identified in D. melanogaster, of which 43 are expressed in the antenna or maxillary palp [47]. In mosquitoes, 79 and 131 putative OR genes have been identified in Anopheles gambiae and Aedes aegypti, respectively $[50,51]$. Given the dramatic sequence divergence of the other ORs between different insect species, it is difficult to identify these sequences by sequence homology, which may explain why only two OR sequences were identified in our preliminary screening of the medfly sequences.

Little is known about the genes involved in reception and behavior in the medfly. This gene discovery study thus represents a unique opportunity to explore the molecular bases of these behavioral traits in the reproductive biology of this important economic pest species. In the long term, the results of the study will aid the development of more efficient sex attractants for the detection, monitoring, and control of this species $[52,53]$.

\section{Genes involved in reproductive behavior}

A total of 27 assembled sequences shared homology with 20 Drosophila genes known to be involved in reproductive behavior (Table 5). In Drosophila, the majority of these genes are involved in male courtship behavior. Mutants for the gene quick-to-court initiate courtship toward virgin females abnormally quickly and also readily attempt to court other males [54]. The prospero gene, which is involved in nervous system development, can alter the age of onset of sexual behavior in males: Males carrying a single copy of a prospero mutation court and mate precociously [55]. Other mutations can result in little or no

Table 4: Medfly assembled sequences with best-hit matches to $D$. melanogaster odorant receptor protein genes

\begin{tabular}{cccccc}
\hline & Drosophila Gene & Alignment Length (aa) & e-Value & Identity (\%) & Similarity (\%) \\
\hline HS336 & Or59a & 68 & $2 \mathrm{E}-14$ & 47 & 69 \\
HS2079 & Or83b & 268 & IE-I36 & 91 & 94 \\
\hline
\end{tabular}


Table 5: Medfly assembled sequences with best-hit matches to $D$. melanogaster genes involved in reproductive behaviour

\begin{tabular}{|c|c|c|c|c|c|c|}
\hline & Drosophila Gene & Alignment Length (aa) & e-value & Identity (\%) & Similariy (\%) & Gene Ontology \\
\hline FC45I & technical knockout & 148 & $5 E-60$ & 77 & 82 & male courtship behavior \\
\hline FC774 & Esterase 6 & 220 & 7E-74 & 58 & 75 & sperm competition \\
\hline $\mathrm{FCI} 294$ & lingerer & 261 & IE-I02 & 69 & 73 & copulation \\
\hline FCI37I & no on or off transient $A$ & 76 & 7E-07 & 43 & 48 & male courtship behavior, song production \\
\hline FCI528 & courtless & 166 & $6 \mathrm{E}-91$ & 95 & 98 & male courtship behavior, spermatogenesis \\
\hline FC204I & no on or off transient $A$ & 144 & $2 \mathrm{E}-82$ & 79 & 89 & male courtship behavior, song production \\
\hline FSI 306 & Dopa decarboxylase & 165 & $2 \mathrm{E}-82$ & 84 & 94 & courtship behavior \\
\hline FSI 728 & Fmrl & 76 & $8 \mathrm{E}-17$ & 56 & 59 & male courtship behavior \\
\hline FSI87I & Shaker & 70 & IE-06 & 45 & 50 & courtship behavior \\
\hline FS2 108 & Calcium/calmodulin & III & $3 E-59$ & 97 & 99 & courtship behavior-dependent protein kinase II \\
\hline FS2293 & gomdanji & 67 & $2 \mathrm{E}-09$ & 37 & 61 & courtship behavior \\
\hline FS2531 & Fmrl & 34 & $5 \mathrm{E}-12$ & 97 & 97 & male courtship behavior \\
\hline FS2790 & quick-to-court & 259 & $9 \mathrm{E}-78$ & 61 & 68 & male courtship behavior \\
\hline $\mathrm{HC} 32 \mathrm{I}$ & takeout & 210 & $\mathrm{IE}-47$ & 41 & 62 & $\begin{array}{l}\text { circadian rhythm, feeding behavior, male } \\
\text { courtship behavior, rhythmic behavior }\end{array}$ \\
\hline $\mathrm{HClO}$ & courtless & 166 & $7 E-91$ & 95 & 98 & $\begin{array}{l}\text { courtship behavior, male meiosis, } \\
\text { spermatogenesis }\end{array}$ \\
\hline $\mathrm{HCl} 68 \mathrm{I}$ & takeout & 245 & $4 \mathrm{E}-6 \mathrm{I}$ & 44 & 65 & $\begin{array}{l}\text { circadian rhythm, feeding behavior, male } \\
\text { courtship behavior, rhythmic behavior }\end{array}$ \\
\hline $\mathrm{HCl} 876$ & timeless & 260 & $6 \mathrm{E}-57$ & 46 & 59 & circadian behavior, copulation \\
\hline HC2478 & dunce & 246 & $5 \mathrm{E}-84$ & 67 & 69 & $\begin{array}{l}\text { circadian rhythm, courtship behavior, oogenesis, } \\
\text { olfactory learning }\end{array}$ \\
\hline HS48 & paralytic & 48 & $4 \mathrm{E}-09$ & 60 & 66 & $\begin{array}{l}\text { male courtship behavior, song production, muscle } \\
\text { contraction }\end{array}$ \\
\hline HS355 & prospero & 100 & IE-55 & 87 & 94 & courtship behavior, sensory perception of taste \\
\hline HS445 & slowpoke & 146 & $5 \mathrm{E}-77$ & 98 & 100 & $\begin{array}{l}\text { male courtship behavior, song production, } \\
\text { circadian rhythm }\end{array}$ \\
\hline HS790 & quick-to-court & 95 & $5 \mathrm{E}-4 \mathrm{I}$ & 89 & 93 & courtship behavior, male courtship behavior \\
\hline HSII99 & ken and barbie & 288 & $6 \mathrm{E}-83$ & 55 & 65 & copulation, genitalia morphogenesis, insemination \\
\hline HS2483 & takeout & 179 & $2 \mathrm{E}-32$ & 39 & 59 & $\begin{array}{l}\text { circadian rhythm, feeding behavior, male } \\
\text { courtship behavior, rhythmic behavior }\end{array}$ \\
\hline HS2917 & lingerer & 35 & $3 \mathrm{E}-14$ & 94 & 94 & copulation \\
\hline HS308I & logjam & 238 & $6 E-99$ & 74 & 84 & $\begin{array}{l}\text { oviposition, protein carrier activity, intracellular } \\
\text { protein transport }\end{array}$ \\
\hline HS3537 & Sphingosine kinase 2 & 178 & IE-30 & 41 & 54 & flight behavior, oviposition, signal transduction \\
\hline
\end{tabular}

courtship behavior (courtless and takeout) and produce defects in spermatogenesis (takeout) [56,57]. Mutations in the dunce and Calcium calmodulin kinase II genes disrupt the ability of the male to learn to avoid courting males and mated females [58]. Males with a mutation at one of the clock genes, timeless, display extended copulation times [59] and those with the lingerer mutation court and copulate with females normally, but subsequently have great difficulty in disengaging their genitalia [60]. Hyperexcitability mutations in the potassium channels encoded by the Shaker gene result in courtship suppression. Other mutants such as paralytic and slowpoke affect the sodium channel and calcium activated potassium channel, respectively, and result in defective courtship song production [58]. Finally, mutations in a mitochondrial ribosomal protein gene, technical knockout, result in unsuccessful male courtship behavior, apparently because of a hearing impediment [61].
One of the two medfly assembled sequences that may be involved in female reproductive behavior has homology to the Drosophila logjam (loj) gene. Females carrying mutations in loj mate normally and store sperm just as normal females do, but they do not lay eggs. The loj mutation has no observable effect on male courtship behavior and fertility. The gene encodes a member of a family of putative vesicle cargo receptor proteins that may mediate the transmission of positive signals for oviposition from the central and ventral nerve cord [62]. The other medfly sequence that may be involved in female reproductive behavior has homology to the Sphingosine kinase 2 gene. Drosophila females with a mutation in this gene have reduced flight activity and fecundity. The reduced fecundity of these Sk2 mutants is due to retention of mature eggs in the ovaries, which may be the result of compromised ovarian function or a defect in either sperm storage or the response to seminal fluid proteins [63]. 
The reproductive and sexual behavior of the medfly is relatively well studied [64-66]. Receptive females are attracted to aggregations (leks) of "signaling" males emitting a sex pheromone, which also acts as an attractant for other males. The male orientates towards the female, deflects his abdomen ventrally and begins to vibrate his wings in a continuous manner, apparently wafting a plume of pheromone from his everted rectal pheromone sac toward the female. After a while the male switches to a rhythmic backwards and forwards wing movement while continuing to vibrate rapidly. At this point the rectal pheromone sac is retracted, so the male does not appear to produce pheromone; the female, however, may be stimulated aurally by the sound of the wing movements and visually by rapid movements of the male's head. The male subsequently leaps onto the back of the female, buzzes his wings, and rocks his body back and forth before aligning himself to face the same direction as the female and attempting to copulate. Copulation usually lasts up to $3 \mathrm{hr}$. Throughout the courtship, the female can terminate the affair by merely leaving, dislodging the male, or by refusing to copulate. After insemination, the female's behavior changes from mate-searching to hostfruit location for oviposition [64].

The courtship behavior of Drosophila has been studied in far greater detail and involves a series of steps: orientation, following, tapping, wing vibration or "singing," and licking (of the female genitalia), followed by tail curling and copulation [58]. Although the courtship behavior of Drosophila differs from that of the medfly, it is probable that the underlying genetic bases of these behaviors are sufficiently similar to allow the genes identified to be used to modify or disrupt the medfly's reproductive behavior.

\section{Conclusion}

The sequences obtained in this study represent the first major dataset of expressed genes in a tephritid species of agricultural importance. The availability of this resource will support the investigation of numerous questions regarding the biology of the medfly. EST libraries represent a rich source of polymorphic markers, be they SSRs or SNPs, that can be employed in high-throughput genotyping methods for population genetics and ecological studies [67]. The EST sequences will also be of utmost importance for any future project in which the genome of this organism is sequenced. In practical terms, the EST resource represents an arsenal of information that will allow us to develop new control tools, whether chemical or genetic, that are aimed at altering sex determination, reproductive traits and behavior, and host preference. The identification of these genes in C. capitata will also greatly facilitate the isolation of homologous genes in other tephritid species, as the medfly is by no means the only tephritid species of economic importance. It does, how- ever, represent a model species for true fruit flies of the genera Ceratitis, Bactrocera, Dacus, Anastrepha and Rhagoletis, which include agricultural pests in several geographic areas worldwide. The medfly ESTs will also facilitate studies to elucidate the genetics underlying polyphagous and monophagous traits in pest and non-pest tephritid species. The sequences obtained in this study have been arrayed on a $22 \mathrm{~K}$ microarray, which will make it possible for biologically important questions to be addressed by mass expression profile analyses.

\section{Methods \\ Flies}

An established strain, ISPRA, was chosen for the creation of the cDNA libraries. ISPRA was established in 1968 at the European Community Joint Research Centre, Ispra, Italy, with wild medflies from Sicily and Greece. The strain has been maintained in the quarantine facility at the University of Pavia, Italy since 1979. Standard larval and rearing methods were used [68]. For the embryo library, two separate collections of eggs at $<30 \mathrm{~min}$ to $36 \mathrm{hr}$ after oviposition were carried out, with each collection offset by 9 hr (i.e., in the early morning and afternoon). The eggs were filtered from the water and rinsed with distilled water, then with $0.02 \%$ Triton X-100, and finally with diethylpyrocarbonate (DEPC) treated water. To obtain adults for the head library, a standard laboratory rearing cage was set up with about 600 less than 1 day old adults. Twelve males and 12 females were removed from the cage and used for RNA extraction at intervals of $24 \mathrm{hr}$ for 8 days.

\section{cDNA library construction}

For the embryo library, total RNA was extracted from approximately $1 \mathrm{~g}$ (wet weight) of eggs from each collection using Trizol (Invitrogen) according to the manufacturer's instructions, followed by treatment with DNase (DNAfree, Ambion). An equal quantity of total RNA from the two extractions was pooled prior to poly(A)+ RNA purification. For the head library, total RNA was immediately extracted separately from the male and female heads from each collection using Trizol, followed by treatment with DNase. An equal quantity of total RNA from the male head and female head extractions was pooled prior to poly(A)+ RNA purification.

First-strand cDNA synthesis was primed with an oligo(dT) containing a NotI restriction site. The double-stranded cDNA was ligated to an EcoRI adaptor, digested with NotI, and cloned directionally into a NotI- and EcoRI-digested pT7T3-Pac phagemid vector [69]. The cDNA inserts were flanked by a library-specific 3 ' linker tag sequence (5'NotI-TAAGGTCGAG-3' in the embryo library and 5'-NotITCGACACAAT-3' in the head library) and 5' linker (5'- 
EcoRI-GGCACGAGG-3'). Both libraries were normalized [69].

\section{Sequencing and contig assembly}

Randomly selected clones were sequenced from the $5^{\prime}$ end using the M13 reverse sequencing primer (5'-AGCGGATAACAATTTCACACAGGA-3') with an Applied Biosystems 3730 DNA analyzer. Base-calling and low quality sequence trimming were achieved using Phred [70], and vector sequences were trimmed using Cross-match [71]. Repeat sequences were masked using RepeatMasker [72]. The sequences were assembled using Phrap [14]. The resulting assembled sequences were used to perform BLAST searches locally on a Macintosh G5 Unix workstation and on locally installed sequence databases, including the non-redundant protein sequence database and the Drosophila, Anopheles gambiae, and Apis mellifera protein databases. BLAST searches were performed using the lowcomplexity filter with the low-complexity sequences masked. A similarity was considered significant if the $e$ value was lower than $10^{-5}$. GO annotations were derived from the best-hit Drosophila sequences and were obtained for each assembled sequence using FlyBase [73]. The presence of putative ORFs in the assembled sequences (with and without the start codon) was determined using Flip 2.0.2, with the minimum length set to 150 amino acids [74]. The sequences reported in this study have been deposited in GenBank under accession numbers [GenBank: FG068301 - FG089553].

\section{PCR-based cloning of Cctra2}

Two primers based on the sequence of FC1744, Tra2-26f (5'- tcaatcagcggtagcttgtg-3') and Tra2-939r (5'-acgtgtgtttgtttgtttgct-3'), were used to amplify the sequence of the putative Cctra2 gene from genomic DNA isolated from the ISPRA strain. Amplification was performed using the AccuPrime Taq DNA Polymerase High Fidelity Kit (Invitrogen Srl, Milan) using the following conditions: an initial denaturing step at $94^{\circ} \mathrm{C}$ for $1 \mathrm{~min}$, followed by 30 cycles of $30 \mathrm{sec}$ at $94^{\circ} \mathrm{C}, 30 \mathrm{sec}$ at $56^{\circ} \mathrm{C}$, and $3 \mathrm{~min} 30 \mathrm{sec}$ at $68^{\circ} \mathrm{C}$, with a final extension of $10 \mathrm{~min}$. Amplification products were cloned using the TOPO TA cloning kit (Invitrogen) and sequenced on both strands using the Big Dye Ready Reaction kit on an ABI 310 DNA Genetic Analyzer (Applied Biosystems, Foster City, CA).

\section{RT-PCR-based transcript detection}

For transcript detection by RT-PCR, total RNA was extracted using Trizol (according to the manufacturer's instructions; Invitrogen, Milan, Italy) from pools of $\sim 250$ embryos in age ranges of $0-5,5-10,10-15,15-20,20-25$ and 25-30 hr after oviposition; individual third instar larvae; and pools of eight heads and two headless bodies of 1- and 4-day-old adult virgin male and female flies. DNA was extracted from the same samples using the Trizol
DNA extraction protocol. The larvae were sexed using a PCR technique [75]. cDNA was synthesized from $2.5 \mu \mathrm{g}$ of RNA using the Cloned AMV First-Strand cDNA Synthesis Kit (Invitrogen, Milan, Italy). The primers used for the RTPCR were Tra2-26f and Tra2-901r (5'-gcgaataggaacgactacgg-3'). The medfly glucose-6-phosphate dehydrogenase [GenBank: S67872] housekeeping gene was amplified as a control using the primers G6PDH-196f (5'ttgtcatctttggtgcttcg-3') and G6PDH-372r (5'-ccggttgcaccttcatgtat-3'). To control for genomic DNA contamination, RT-PCR was also performed on samples in which cDNA synthesis had been performed in the absence of reverse transcriptase. RT-PCR was performed using $5 \%$ of the synthesized cDNA with the following cycle conditions: $94^{\circ} \mathrm{C}$ for $2 \mathrm{~min}, 30$ cycles at $94^{\circ} \mathrm{C}$ for $30 \mathrm{sec}, 56^{\circ} \mathrm{C}$ for $30 \mathrm{sec}$, $72^{\circ} \mathrm{C}$ for $1 \mathrm{~min}$, and a final extension at $72^{\circ} \mathrm{C}$ for $10 \mathrm{~min}$. The amplification products were electrophoresed on $1.5 \%$ or $2 \%$ agarose gels.

\section{Phylogenetic analysis}

Multiple alignments of putative amino acid sequences were performed using the PRALINE server with the standard progressive strategy [76], and neighbor-joining minimum evolution trees were obtained using PAUP $4.0 \mathrm{~b} 10$ [77]. Maximum-likelihood trees were obtained using the Jones-Taylor-Thornton model of amino acid change in Phylip version 3.67 [78].

\section{Authors' contributions}

LMG, GD, ARM and GG conceived the study, and participated in its design and coordination. LMG performed RNA isolation, genomic sequencing and RT-PCR analyses. MBS and MFB prepared the libraries and performed cDNA sequencing. LMG and ZX performed sequence processing, assembly, annotation and bioinformatic analyses; LMG, GD, ARM and GG drafted the manuscript. All authors read and approved the final manuscript.

\section{Additional material}

\section{Additional file 1}

Table S1. Distribution of BLASTX best hits against the non-redundant protein database ( $\mathrm{nr}$ ).

Click here for file

[http://www.biomedcentral.com/content/supplementary/14712164-9-243-S1.doc]

\section{Additional file 2}

Table S2. Assembled sequences with best-hit matches to known C. capitata sequences.

Click here for file

[http://www.biomedcentral.com/content/supplementary/14712164-9-243-S2.doc] 


\author{
Additional file 3 \\ Table S3. Gene Ontology classification: Molecular Function. \\ Click here for file \\ [http://www.biomedcentral.com/content/supplementary/1471- \\ 2164-9-243-S3.doc]

\section{Additional file 4} \\ Table S4. Gene Ontology classification: Biological Process. \\ Click here for file \\ [http://www.biomedcentral.com/content/supplementary/1471- \\ 2164-9-243-S4.doc]
}

\section{Acknowledgements}

This work was supported by Italian Ministry of Universities and Research PRIN grant number 2004053427 (LMG, ARM, GG), and IR0IAI06I576-

OIAI (GD, ZX). ZX was supported by a Johns Hopkins MRI fellowship. We thank Deborah McClelland for editorial assistance and the Johns Hopkins School of Public Health for computational support. We also thank Tammy Kucaba, Christina Smith and Jared Bischof for their bioinformatics support.

\section{References}

I. Malacrida AR, Gomulski LM, Bonizzoni M, Bertin S, Gasperi G, Guglielmino CR: Globalization and fruitfly invasion and expansion: the medfly paradigm. Genetica 2007, I 3 I: | -9.

2. Krafsur ES: Sterile insect technique for suppressing and eradicating insect populations: $\mathbf{5 5}$ years and counting. I Agriculutural Entomology 1998, 15:303-317.

3. Robinson AS: Genetic control of insect pests. In Biological and Biotechnological Control of Insect Pests Edited by: Rechcigl JE, RechcigI NA Boca Raton: CRC Press; 1999:141-169.

4. Loukeris TG, Livadaras I, Arca B, Savakis C: Gene transfer into the medfly, Ceratitis capitata, using a Drosophila hydei transposable element. Science 1995, 270:2002-2005.

5. The Uniprot Consortium: The Universal Protein Resource (UniProt). Nucleic Acids Research 2007, 35:D193-197.

6. Genomes Online [http://www.genomesonline.org/]

7. Adams MD, Celniker SE, Holt RA, Evans CA, Gocayne JD, Amanatides PG, Scherer SE, Li PW, Hoskins RA, Galle RF, George RA, Lewis SE, Richards S, Ashburner M, Henderson SN, Sutton GG, Wortman JR, Yandell MD, Zhang Q, Chen LX, Brandon RC, Rogers YHC, Blaze RG, Champe M, Pfeiffer BD, Wan KH, Doyle C, Baxter EG, Helt G, Nelson CR, Miklos GLG, Abril JF, Agbayani A, An HJ, Andrews-Pfannkoch C, Baldwin D, Ballew RM, Basu A, Baxendale J, Bayraktaroglu L, Beasley EM, Beeson KY, Benos PV, Berman BP, Bhandari D, Bolshakov S, Borkova D, Botchan MR, Bouck J, Brokstein P, Brottier P, Burtis KC, Busam DA, Butler H, Cadieu E, Center A, Chandra I, Cherry JM, Cawley S, Dahlke C, Davenport LB, Davies A, de Pablos B, Delcher A, Deng ZM, Mays AD, Dew I, Dietz SM, Dodson K, Doup LE, Downes M, Dugan-Rocha S, Dunkov BC, Dunn P, Durbin KJ, Evangelista CC, Ferraz C, Ferriera S, Fleischmann W, Fosler C, Gabrielian AE, Garg NS, Gelbart WM, Glasser K, Glodek A, Gong FC, Gorrell JH, Gu ZP, Guan P, Harris M, Harris NL, Harvey D, Heiman TJ, Hernandez JR, Houck J, Hostin D, Houston DA, Howland TJ, Wei MH, Ibegwam C, Jalali M, Kalush F, Karpen GH, Ke ZX, Kennison JA, Ketchum KA, Kimmel BE, Kodira CD, Kraft C, Kravitz S, Kulp D, Lai ZW, Lasko P, Lei YD, Levitsky AA, Li JY, Li ZY, Liang Y, Lin XY, Liu X), Mattei B, Mclntosh TC, McLeod MP, McPherson D, Merkulov G, Milshina NV, Mobarry C, Morris J, Moshrefi A, Mount SM, Moy M, Murphy B, Murphy L, Muzny DM, Nelson DL, Nelson DR, Nelson KA, Nixon K, Nusskern DR, Pacleb JM, Palazzolo M, Pittman GS, Pan S, Pollard J, Puri V, Reese MG, Reinert K, Remington K, Saunders RDC, Scheeler F, Shen H, Shue BC, Siden-Kiamos I, Simpson M, Skupski MP, Smith T, Spier E, Spradling AC, Stapleton M, Strong R, Sun E, Svirskas $\mathrm{R}$, Tector $\mathrm{C}$, Turner R, Venter E, Wang AHH, Wang $X$, Wang ZY, Wassarman DA, Weinstock GM, Weissenbach J, Williams SM, Woodage T, Worley KC, Wu D, Yang S, Yao OA, Ye J, Yeh RF, Zaveri JS, Zhan M, Zhang GG, Zhao Q, Zheng LS, Zheng XQH, Zhong
FN, Zhong WY, Zhou XJ, Zhu SP, Zhu XH, Smith HO, Gibbs RA, Myers EW, Rubin GM, Venter JC: The genome sequence of Drosophila melanogaster. Science 2000, 287:2 185-2195.

8. The Honeybee Genome Sequencing Consortium: Insights into social insects from the genome of the honeybee Apis mellifera. Nature 2006, 443:931-949.

9. Holt RA, Subramanian GM, Halpern A, Sutton GG, Charlab R, Nusskern DR, Wincker P, Clark AG, Ribeiro JMC, Wides R, Salzberg SL, Loftus B, Yandell M, Majoros WH, Rusch DB, Lai ZW, Kraft CL, Abril $\mathrm{JF}$, Anthouard V, Arensburger $\mathrm{P}$, Atkinson PW, Baden $\mathrm{H}$, de Berardinis $V$, Baldwin D, Benes V, Biedler J, Blass C, Bolanos R, Boscus D, Barnstead M, Cai S, Center A, Chatuverdi K, Christophides GK, Chrystal MA, Clamp M, Cravchik A, Curwen V, Dana A, Delcher A, Dew I, Evans CA, Flanigan M, Grundschober-Freimoser A, Friedli L, Gu ZP, Guan P, Guigo R, Hillenmeyer ME, Hladun SL, Hogan JR, Hong YS, Hoover J, Jaillon O, Ke ZX, Kodira C, Kokoza E, Koutsos A, Letunic I, Levitsky A, Liang Y, Lin J], Lobo NF, Lopez JR, Malek JA, Mclntosh TC, Meister S, Miller J, Mobarry C, Mongin E, Murphy SD, O'Brochta DA, Pfannkoch C, Qi R, Regier MA, Remington K, Shao HG, Sharakhova MV, Sitter CD, Shetty J, Smith T], Strong R, Sun JT, Thomasova D, Ton LQ, Topalis P, Tu ZJ, Unger MF, Walenz B, Wang AH, Wang J, Wang M, Wang XL, Woodford KJ, Wortman JR, Wu M, Yao A, Zdobnov EM, Zhang HY, Zhao O, Zhao SY, Zhu SPC, Zhimulev I, Coluzzi M, della Torre A, Roth CW, Louis C, Kalush F, Mural RJ Myers EW, Adams MD, Smith HO, Broder S, Gardner MJ, Fraser CM, Birney E, Bork P, Brey PT, Venter JC, Weissenbach J, Kafatos FC, Collins $\mathrm{FH}$, Hoffman SL: The genome sequence of the malaria mosquito Anopheles gambiae. Science 2002, 298: I29-| 49.

10. Xia QY, Zhou ZY, Lu C, Cheng DJ, Dai FY, Li B, Zhao P, Zha XF, Cheng TC, Chai CL, Pan GQ, Xu JS, Liu C, Lin Y, Qian JF, Hou Y, Wu ZL, Li GR, Pan MH, Li CF, Shen YH, Lan XO, Yuan LW, Li T, Xu HF Yang GW, Wan YJ, Zhu Y, Yu MD, Shen WD, Wu DY, Xiang ZH, Yu J, Wang J, Li RQ, Shi JP, Li H, Li GY, Su JN, Wang XL, Li GQ, Zhang Z], Wu QF, Li J, Zhang QP, Wei N, Xu JZ, Sun HB, Dong L, Liu DY, Zhao SL, Zhao XL, Meng QS, Lan FD, Huang XG, Li YZ, Fang L, Li CF, Li DW, Sun YQ, Zhang ZP, Yang Z, Huang YQ, Xi Y, Qi QH, He DD, Huang HY, Zhang XW, Wang ZQ, Li W], Cao YZ, Yu YP, Yu H, Li $J H$, Ye JH, Chen H, Zhou Y, Liu B, Wang J, Ye J, Ji H, Li ST, Ni PX, Zhang JG, Zhang Y, Zheng HK, Mao BY, Wang W, Ye C, Li SG, Wang J, Wong GKS, Yang HM: A draft sequence for the genome of the domesticated silkworm (Bombyx mori). Science 2004, 306: 1937-1940.

II. Ensembl [http://www.ensembl.org]

12. Wellcome Trust Sanger Institute [http://www.sanger.ac.uk]

13. Heckel DG: Genomics in pure and applied entomology. Annu Rev Entomol 2003, 48:235-260.

14. Phrap [http://www.phrap.com/]

15. Davies S], Chapman T: Identification of genes expressed in the accessory glands of male Mediterranean fruit flies (Ceratitis capitata). Insect Biochemistry and Molecular Biology 2006, 36:846-856

16. Gomulski LM, Torti C, Murelli V, Bonizzoni M, Gasperi G, Malacrida AR: Medfly transposable elements: diversity, evolution, genomic impact and possible applications. Insect Biochemistry and Molecular Biology 2004, 34: I39-I48.

17. Beverley SM, Wilson AC: Molecular evolution in Drosophila and the higher Diptera. II. A time scale for fly evolution. Journal of Molecular Evolution 1984, 2 I : I- I3

18. Kwiatowski J, Krawczyk M, Jaworski M, Skarecky D, Ayala FJ: Erratic evolution of glycerol-3-phosphate dehydrogenase in Drosophila, Chymomyza, and Ceratitis. Journal of Molecular Evolution 1997, 44:9-22.

19. Saccone G, Pane A, Polito LC: Sex determination in flies, fruitflies and butterflies. Genetica 2002, I I 6: I 5-23.

20. Pane A, De Simone A, Saccone G, Polito C: Evolutionary conservation of Ceratitis capitata transformer gene function. Genetics 2005, I 71:615-624.

21. Ruiz MF, Milano A, Salvemini M, Eirín-López JM, Perondini ALP, Selivon D, Polito C, Saccone G, Sánchez L: The gene Transformer of Anastrephafruit flies (Diptera, Tephritidae) and its evolution in insects. PLOS ONE 2007, 2: el 239.

22. Burghardt G, Hediger M, Siegenthaler C, Moser M, Dübendorfer A, Bopp D: The transformer2 gene in Musca domestica is required for selecting and maintaining the female pathway of development. Dev Genes Evol 2005, 2 15:165-176. 
23. Breathnach R, Chambon P: Organization and expression of eukaryotic split genes coding for proteins. Annu Rev Biochem I 981, 50:349-383.

24. Marchier-Bauer A, Bryant SH: CD-search: protein domain annotations on the fly. Nucleic Acids Res 2004:327-33I.

25. Amrein $\mathrm{H}$, Hedley ML, Maniatis $\mathrm{T}$ : The role of specific proteinRNA and protein-protein interactions in positive and negative control of pre-messenger-RNA splicing by transformer-2. Cell 1994, 76:735-746.

26. Mattox W, Palmer MJ, Baker BS: Alternative splicing of the sex determination gene transformer-2 is sex-specific in the germline but not in the soma. Genes \& Dev 1990, 4:789-805.

27. Soto-Adames FN, Robertson HM, Berlocher SH: Phylogenetic utility of partial DNA sequences of G6pdh at different taxonomic levels in Hexapoda with emphasis on Diptera. Ann Entomol Soc Am 1994, 87:723-736.

28. Gomulski LM, Pitts RJ, Costa S, Saccone G, Torti C, Polito LC, Gasperi G, Malacrida AR, Kafatos FC, Zwiebel LJ: Genomic organization and characterization of the white locus in the mediterranean fruitfly, Ceratitis capitata. Genetics 2001, 157:1245-1255

29. Brogna S, Benos PV, Gasperi G, Savakis C: The Drosophila alcohol dehydrogenase gene may have evolved independently of the functionally homologous medfly, olive fly and flesh fly genes. Mol Biol Evol 2001, I 8(3):322-329.

30. Crampton GC: A comparative morphological study of the terminalia of male calyptrate cyclorrhaphous diptera and their acalyptrate relatives. Bull Brooklyn Entomol Soc 1944, 34: I-34

31. Lam BJ, Bakshi A, Ekinci FY, Webb J, Graveley BR, Hertel KJ: Enhancer-dependent 5'-splice site control of fruitless premRNA splicing. J Biol Chem 2003, 278:22740-22747.

32. Rideout EJ, Billeter J-C, Goodwin SF: The sex-determination genes fruitless and doublesex specify a neural substrate required for courtship song. Current Biology 2007, I 7:|473-|478.

33. Schütt $C$, Nöthiger R: Structure, function and evolution of sexdetermining systems in Dipteran insects. Development 2000 , I 27:667-677.

34. Baker R, Herbert RH, Grant GG: Isolation and identification of the sex pheromone of the Mediterranean fruit fly Ceratitis capitata (Wied). J Chem Soc, Chem Commun 1985:824-825.

35. Justice RW, Biessmann H, Walter MF, Dimitratos SD, Woods DF: Genomics spawns novel approaches to mosquito control. BioEssays 2003, 25:1011-1020.

36. Hallem EA, Dahanukar A, Carlson JR: Insect odor and taste receptors. Annu Rev Entomol 2006, 5 I: II3-135.

37. Pelosi P: Odorant-binding proteins. Crit Rev Biochem Mol Biol 1994, 29:199-228.

38. Kim M, Repp A, Smith D: LUSH odorant-binding protein mediates chemosensory responses to alcohols in Drosophila melanogaster. Genetics 1998, I50:71 I-72I

39. Hekmat-Scafe DS, Scafe CR, McKinney AJ, Tanouye MA: Genomewide analysis of the odorant-binding protein gene family in Drosophila melanogaster. Genome Research 2007, I 2: I357-I 369.

40. Pelosi P, Maida R: Odorant-binding proteins in insects. Comp Biochem Physiol B Biochem Mol Biol 1995, I I I:503-5 I4.

4I. Thymianou S, Mavroidis M, Kokolakis G, Komitopoulou K, Zacharopoulou A, Mintzas AC: Cloning and characterisation of a cDNA encoding a male-specific serum protein of the Mediterranean fruit fly, Ceratitis capitata, with sequence similarity to odourant-binding proteins. Insect Mol Biol 1998, 7:345-353.

42. Christophides GK, Mintzas AC, Komitopoulou K: Organization, evolution and expression of amultigene family encoding putative members of the odorant binding protein family in the medfly Ceratitis capitata. Insect Molecular Biology 2000, 9:185-195.

43. Biessmann H, Walter MF, Dimitraros S, Woods D: Isolation of cDNA clones encoding putative odorant binding proteins from the antennae of the malaria-transmitting mosquito, Anopheles gambiae. Insect Molecular Biology 2002, I I: I 23-I32.

44. Jones WD, Nguyen TA, Kloss B, Lee KJ, Vosshall LB: Functional conservation of an insect odorant receptor gene across 250 million years of evolution. Current Biology 2005, I 5:RI I 9-RI2I

45. Fishilevich E, Domingos Al, Asahina K, Naef F, Vosshall LB, Louis M: Chemotaxis behaviour mediated by single larval olfactory neurons in Drosophila. Current Biology 2005, I 5:2086-2096.
46. Kreher SA, Kwon JY, Carlson JR: The molecular basis of odor coding in the Drosophila larva. Neuron 2005, 46:445-456.

47. Vosshall LB, Stocker RF: Molecular architecture of smell and taste in Drosophila. Ann Rev Neurosci 2007, 30:505-533.

48. Vosshall LB, Wong A, Axel R: An olfactory sensory map in the fly brain. Cell 2000, 102:147-159.

49. Flyatlas [http://www.flyatlas.org]

50. Hill CA, Fox AN, Pitts RJ, Kent LB, Tan PL, Chrystal MA, Cravchik A, Collins FH, Robertson HM, Zwiebel LJ: G protein-coupled receptors in Anopheles gambiae. Science 2002, 298: I76-I 78.

5I. Bohbot J, Pitts RJ, Kwon H-W, Rützler M, Robertson HM, Zwiebel LJ: Molecular characterization of the Aedes aegypti odorant receptor gene family. Insect Molecular Biology 2007, I 6:525-537.

52. Mclnnis DO, Shelly TE, Komatsu J: Improving male mating competitiveness and survival in the field for medfly, Ceratitis capitata (Diptera: Tephritidae) SIT programs. Genetica 2002, I 16:1 17-I124.

53. Katsoyannos BI, Papadopoulos NT: Evaluation of synthetic female attractants against Ceratitis capitata (Diptera: Tephritidae) in sticky coated spheres and McPhail type traps. J Econ Entomol 2004, 97(I):2I-26.

54. Gaines P, Tompkins L, Woodard CT, Carlson JR: quick-to-court, a Drosophila mutant with elevated levels of sexual behaviour, is defective in a predicted coiled-coil protein. Genetics 2000 , I 54: | 627-1637.

55. Grosjean Y, Guenin L, Bardet HM, Ferveur JF: Prospero mutants induce precocious sexual behaviour in Drosophila males. Behav Genet 2007, 37:575-584.

56. Orgad S, Rosenfeld G, Greenspan RJ, Segal D: courtless, the Drosophila UBC7 homolog, is involved in male courtship behavior and spermatogenesis. Genetics 2000, I 55: | 267- 1280.

57. Dauwalder B, Tsujimoto S, Moss J, Mattox W: The Drosophila takeout gene is regulated by the somatic sex-determination pathway and affects male courtship behaviour. Genes \& Development 2002, 16:2879-2892.

58. Greenspan RJ, Ferveur J-F: Courtship in Drosophila. Annu Rev Genet 2000, 34:205-232.

59. Beaver LM, Giebultowicz JM: Regulation of Copulation duration by period and timeless in Drosophila melanogaster. Current Biology 2004, I 4: |492-| 497.

60. Kuniyoshi H, Baba K, Ueda R, Kondo S, Awano W, Juni N, Yamamoto $\mathrm{D}$ : lingerer, a Drosophila gene involved in initiation and termination of copulation, encodes a set of novel cytoplasmic proteins. Genetics 2002, I 62: I775-I789.

6I. Toivonen JM, O'Dell KM, Petit N, Irvine SC, Knight GK, Lehtonen M, Longmuir M, Luoto K, Touraille S, Wang Z, Alziari S, Shah ZH, Jacobs HT: Technical knockout, a Drosophila model of mitochondrial deafness. Genetics 200I, I 59:241-254.

62. Carney GE, Taylor BJ: logjam encodes a predicted EMP24/GP25 protein that is required for Drosophila oviposition behaviour. Genetics 2003, 164:173-186.

63. Herr DR, Fyrst H, Creason MB, Phan VH, Saba JD, Harris GL: Characterisation of the Drosophila sphingosine kinases and requirement for $\mathbf{S k 2}$ in normal reproductive function. The Journal of Biological Chemistry 2004, 279: I 2685-I 2694.

64. Eberhard W. Sexual behavior and sexual selection in the Mediterranean fruit fly, Ceratitis capitata (Dacinae: Ceratitidini). In Fruitflies (Tephritidae): phylogeny and evolution of behavior Edited by: Aluja M, Norrbom A. Boca Raton: CRC Press; 2000:457-489.

65. Sivinski J, Aluja M, Dodson GN, Freidberg A, Headrick DH, Kaneshiro KY, Landolt PJ: Topics in the evolution of sexual behavior in the Tephritidae. In Fruitflies (Tephritidae): phylogeny and evolution of behavior Edited by: Aluja M, Norrbom A. Boca Raton: CRC Press; 2000:75I-792

66. Yuval B, Hendrichs J: Behavior of flies in the genus Ceratitis (Dacinae: Ceratitidini). In Fruitflies (Tephritidae): phylogeny and evolution of behavior Edited by: Aluja M, Norrbom A. Boca Raton: CRC Press; 2000:429-458.

67. Bouk A, Vision T: The molecular ecologist's guide to expressed sequence tags. Molecular Ecology 2007, I 6:907-924.

68. Saul SH: Rearing methods for the medfly, Ceratitis capitata. Ann Entomol Soc Am 1982, 75:480-483.

69. Bonaldo MDF, Lennon G, Soares MB: Normalization and subtraction: Two approaches to facilitate gene discovery. Genome Research 1996, 6:791-806. 
70. Ewing B, Hillier L, WendI MC, Green P: Basecalling of automated sequencer traces using phred. I. Accuracy assessment. Genome Research 1998, 8:175-185.

71. Crossmatch [http://www.sanger.ac.uk/software/]

72. Smit AFA, Hubley R, Green P: RepeatMasker Open-3.0. 2004 [http://www.repeatmasker.org].

73. Flybase batch server [http://chervil.bio.indiana.edu:7092/search/ fbidbatch.hform]

74. Flip [http://www.bch.umontreal.ca/ogmp/aboutflip.html]

75. Douglas LJ, Untalan PM, Haymer DS: Molecular sexing in the Mediterranean fruit fly. Ceratitis capitata 2004, 34:159- 165.

76. Simossis VA, Heringa J: The PRALINE online server: optimising progressive multiple alignment on the web. Comput Biol Chem 2003, 27:5II-519.

77. Swofford DL: PAUP*: Phylogenetic Analysis Using Parsimony (*and Other Methods), Version 4 Sinauer Associates, Sunderland, MA; 1998.

78. Felsenstein J: PHYLIP (Phylogeny Inference Package) version 3.6. Distributed by the author. Department of Genome Sciences, University of Washington, Seattle 2004.

79. AMIGO [http://amigo.geneontology.org]

Publish with Bio Med Central and every scientist can read your work free of charge

"BioMed Central will be the most significant development for disseminating the results of biomedical research in our lifetime. "

Sir Paul Nurse, Cancer Research UK

Your research papers will be:

- available free of charge to the entire biomedical community

- peer reviewed and published immediately upon acceptance

- cited in PubMed and archived on PubMed Central

- yours - you keep the copyright

Submit your manuscript here:

http://www.biomedcentral.com/info/publishing_adv.asp
BioMedcentral 